\title{
The Question of Right to Water: Some Reflections on the Major debates in Political Discourse
}

\author{
Deepti Acharya \\ Assistant Professor Department of Political Science Faculty of Arts \\ The Maharaja Sayajirao University of Baroda, Vadodara
}

\begin{abstract}
Rights talks are normative inquiries. Fundamentally, it insists to find what is supposed to be claimed as right and what decides its claimability. Unarguably, whatever is essential for life is a right. Since water is one of the essentials of life, it indeed is a right. The aim of this paper, in this view, is, not to argue against or in favor of the idea of right to water but the aim is to highlight the existing logics that has endorsed that water is a right. In political discourse, such logics are remarkably different as they have elaborated the right in different contexts and have justified them for different purposes.

Present paper in this respect is investigating and commenting on some major debates on the question of right to water, this includes debates advanced in neo-liberalism, neo-Marxism, Eco-feminism and Human Right discourse. The paper presents some observations on each debate and tries to find the problem lies in them. For this purpose the paper is divided into four parts, each of which is followed by some observations.
\end{abstract}

Key Words: Right to water, Neo liberalism, Neo-Marxism, Eco-feminism and Human rights

\section{Background}

In water literature, concept of right to water is discussed for different purposes and so have different logics. It is noted that in the academia, explanations on water as a right are processed as thesis, antithesis and synthesis. To understand the process in political discourse, this paper initially focuses on three ideas that are attaching to the idea of right to water. The first idea of which presents that water as a question of right is not a theoretical acclamation. As a notion it is conceptualized with debates, arises in diverse ways and from different perspectives as Iyer (2010) observes ${ }^{1}$. Second idea is inseparably attached with the first one, which states that the idea that water is a right, has many logics. It emphasis that the question of right to water is not a mere outcome of political argument, but it essentially comprises debates developed with social, legal and economic interpretations. There are several examples of such interpretations. Hoelstra's input is one of such. To elaborate water as a right he has adopted the Cultural Theory of Thompson. With the cultural theory as the background, he ascribed that the approaches like hierarchist, egalitarian, individualist and fatalist have virtue of cultural relevance that provides better alternatives to maintain water as a right. Understandings developed by the scholars like Gleick (1996), Lundqvist (1997) and Iyer (2001) are equally important as they have conceptualized water with legal perceptions. According to them, the idea that water is right have legal justifications, with the help of which it satisfies the basic needs of all living beings (Shiva includes environment in this, 2001). The contrast contribution is noticed in Bower, Kindler, Russell \& Sewell, (1984) and Rogers (1985)'s thesis, who have collectively argued that the question of right to water is required to be addressed with economic perception, it is essential to discussed it as a commodity. For them, right to water is a claim, entitlement of which enables individuals to use water for domestic or other purposes. They insist that since use of water is multiple, usability of it must be charged. The third idea is a consequence of the two that provides that the discussion on water, that maintains water as a right, is rigorous in political discourse. It is, because each argument is evolved with contextual logics and has political, social, economic and administrative influences, at global level. It is noted that the difference of argument has developed a discourse that intensively argues that water is a right. Presenting these discussions and debates is the real purpose of present paper. For this, debates advanced in modern political discourse is taken with a believe that the discussion will offer a precise understanding on the idea of right to water.

\footnotetext{
${ }^{1}$ Iyre's analysis is not theoretical discussion on water right/right to water, but is fundamentally based on the conflict studies (see page 95: water: perspectives, issues and concerns). He has analyzed water as issues like riparian, federalist, formal law, civil society, participatory and stakeholders, environmentalist, economic and human right. For details see: Prasad, K. (2015), Water in the coming decades: Policy and Governance Issues in India. Delhi : Foundation.
} 
The first argument in discourses of water as a right is indeed developed in the neoliberal perception, which is followed by neo Marxist, eco- feminist and human right perceptions. The four are found important because each of it is representing different scenario and arguing accordingly. Like, neo-liberalist approach is representing economic understandings on right to water, Neo-Marxist is a combination of political, social and economic interpretations and eco-feminist is highlighting the social phenomena of right to water. An understanding developed in human right is entirely different in this regards as it has amalgamated the three. I argue that comprehensively, all four together creates possibilities to attain right to water rightly and provides strong grounds to right to water but the unavoidable limitations.

\section{NEO-LIBERAL PERCEPTION}

The first argument of water is a right contains liberalist perception known as neo-liberalism ${ }^{2}$. Since principles of neo-liberalism are fundamentally based on liberalism, like liberalism it is focusing on freedom of using water and has argued it favor of utility. The idea insists that the highest value of right to water lies in its utility, it is noted that to justify that water is a right, liberals have used arguments advanced in utilitarianism ${ }^{3}$. Scholars of this believe perceive the issue of water as a consequential right ${ }^{4}$. The perception is principally based on two questions. The first is for what purpose water is claimed as a right and the second is, if use of water can add to maximum utility? Here, the term utility is not used for social preferences i.e., equality but it has been argued to attain economic objectives, i.e. profit (Bakker, 2010: 138). It implies that whoever can produce maximum utility as profit can lay claim on water as his/her right. This has made water a transferable right which insists on transferring the right to use water from the small uses (drinking and domestic) to big uses (agriculture and industry) i.e. from less productive to more productive uses ${ }^{5}$ (Easter, 1998,: Chong \& Sunding, 2006: Griffin R. 1992: Hearne, 2000). Thus the notion evolved in liberals has seen use of water in the virtue of profit ${ }^{6}$. Branco \& Damiao (2012) have observed it as an individualistic, utilitarian and equilibrium driven idea that is based on the mathematical foundation, which calculates everything with cast and benefit. Objectively, it has nothing to do with the idea of maximum equality ${ }^{7}$. It is clear that for neoliberals, the reason to argue for right to water is to create maximize utility, for which they argue it as a right of ownership, the logic of which has divided things into matter of public and private ownership ${ }^{8}$. To justify the argument they (neoliberals) presents that anything which gets reduced by its use cannot be considered as a public good ${ }^{9}$. In this respect it is argued that since the quantity of water reduces as per its use, it cannot be claimed and maintained as a public good, especially in the situation of water stress ${ }^{10}$. Thus, another justification of neoliberals that water is a right lies in the reference of water shortage and water scarcity. While investigating the situations like scarcity, they insist on paying special attention on efficiency in water management. In neo-liberal thinking and language, effective management of water is possible only by treating it (as much as possible) as a commodity and making it a right to ownership rather than by social or political values of equity or fair play (Barlow 1999; Bond 2000; Cleaver

\footnotetext{
${ }^{2}$ Manuel Couret Branco and Pedro Damião Henriques in their working paper "The Political Economy of the Human Right to Water" (2008), discussed rights as neoclassic ideas. Their basic argument is that human right to water is valued as purchasing power in political economy that has obvious contradictions with human right to water.

${ }^{3}$ It is to be noted that there is a kinship relations between neoliberalism and utilitarianism as both are by nature individualist and profit oriented. In this pattern, Sangameswaran, (2007), has dicussed the question of water as a matter of capabilities.

${ }^{4}$ Please note that consequentiality is not taken as a concept here. I agree with Mill's perception of utility that is studied as utilitarian but his arguments are often considered under the category of consequentiality.

${ }^{5}$ The thought is ideally attached with the idea of maximum utility that obviously has economic interpretations.

${ }^{6}$ Utilitarian understandings with economic efficiency in water distribution have made water a subject of political economy.

${ }^{7}$ The perception is otherwise justified on the ground that rights are mere means and not a separate aim (Parfit D, 1990).

${ }^{8}$ I am arguing the economic value of water as a right and as an aspect of neoliberalism. The term is discussed in the reference of David Harvey (A brief History of Neoliberalism Oxford, Oxford University Press, 2007) who described neoliberalism as an idea, philosophy, policy and process.

${ }^{9}$ Excellent arguments are given by Manuel Couret Barance and Pedro Damiao Henriques (2008), in The Political Economy of the Human Right to Water, working paper, Portugal.

10 I understood that water stress is not the only indication of water scarcity but in this, I include water floods as well. I believe that water stress is a situation when drinkable water is not made available, which is equally observed during floods as well. Hence, throughout my argument is that abundance of water cannot confirm water as a right; it can be assured only with the effective and just management.
}

DOI: 10.9790/0837-2203030108 $\quad$ www.iosrjournals.org 2 Page


and Elson 1995; Lipschutz 1998; McAfee 1999; Spiertz and Wiber 1996) ${ }^{11}$. Foundations of ownership of water are found in Lockeian account ${ }^{12}$, he presumed that water cannot be used without adding labour to it. According to him, a person who has added labour into water is the owner. The idea is further extended in Nozick's account. By removing the idea of morality form the Lockeian proviso i.e. enough water should be left for others. He argues water as a right of an individual, which cannot be taken back without her/his consent. A person as an owner has right to sell the water in his/her terms and conditions that is certainly based on his own profit. Argument like such endorsed that right to use water is not a free right but it is a right attached with a price tag. It is argued that use of water, for whatever purposes is impossible without proper management, which obviously has a cost. Thus, in neoliberal sense, water is not a free gift of nature but is an increasingly rare resource that needs effective and efficient management, the absence of which creates conflicting situations between different users. Since idea is fundamentally based on the values of individualism, it ascribes water as a right of an individual $^{13}$. As it is attach with utility, primarily it works for personal benefit and then for the use of others (Owen, 2001).

\subsection{Observation:}

Liberalist believe with its principle of utility has some limitations. Since the philosophy intends to explore maximum utility of water with limited space for water equality, I argue that working principle, developed in the idea, denies both negative and positive principles of rights. It has discouraged the idea of right on water as a part of right to life and reduces the value of positive right by refusing to facilitate water reach or availability to all. During water shortage and scarcity, the implementation of ideas becomes more dangerous. In such situations, to maximize the utility, water will have high price of use that indeed will not allow a poor to have water, even for his/her most basic need. This certainly rejects the idea of individual right (McGee2004). I strongly believe that the idea of utility is fundamentally wrong as utility of water cannot be measured in figures alone. The significance of water in human life is so vast that it is difficult it to limit it to mathematical calculations. The liberalist perspective has described maximum utility as the maximum use of water for productivity. This means that denial of right to use water for domestic purposes is justifiable, as use of same amount of water for some other purpose (like industrial) can produce more and generate more profit. It clears that the principles of utility has valued materials over life. The question that arises is what is the meaning of profit without having means of sustenance for life? Indeed, perceptions and faiths of liberals has made water a right that is significantly trade related and a market friendly human right (Baxi U, 2006: 252). Unfortunately, this has ultimately restricted right to water as a result of the proviso ${ }^{14}$. With all limitations the argument holds an unavoidable fact that the just use of idea of utility may control water wastage and water pollution. The parties responsible for the same may punish by the legitimate authorities as they have reduced the usability of water.

\section{NEO-MARXIST PERCEPTION}

In Marxist understanding, discussions on water as a right developed as neo-Marxist perception, arguments of which are mainly against individual rights, as it leads to privatization. Instead of focusing on the question of what is right to water, the notion of neo-Marxism has highlighted the limitations of neo-liberal arguments. Thoughts are notably discussed in the reference of environmentalism that has criticized the individualist interpretations of right to water. Since it creates scope for water privatization, Neo Marxists have criticized neoliberalism as "liberal environmentalism" (Bernstein 2001), "green neoliberalism" (Goldman 2005), market environmentalism (Bakker 2004) and as "neoliberalization of nature" (Bridge 2004; Mansfield 2004; McAfee 2003; McCarthy 2004; McCarthy and Prudham 2004; Perrault 2006). Tendencies of "New"

11 Cited in "The water question in feminism: water control and gender inequities" in a neo-liberal era Rhodante Ahlers \& Margreet Zwarteveen Gender, Place \& Culture Gender, Place and Culture Vol. 16, No. 4, August 2009, 409-426. To understand these debates see details of the Dublin Rio principles (2002) and terms and conditions of GAAT and WB for financing water management. Bakker describes these principles as the most influential set of policy principles over the last two decades (now three decades).

12 Locke's opine is not creating unlimited ownership rights on water as in his perception ability of ownership has a moral limitation that insists on leaving enough for others.

${ }^{13}$ Here individual is not singular term but it is plural, which includes private groups as well.

${ }^{14}$ Term used by Nozick's for interpretation of property rights. 
discussions ${ }^{15}$ transformed the nature of global debates (Parmar, 2008: Redgewell, 1996) into global struggle of water. Globally, it is evloved as Global Justice Movement (Shiva 2001, Bakker 2001 and Radha 2010) ${ }^{16}$ that has ascertained right to water as a freedom to use water (Parmar, 2008). It insists that right to water is not a right of individual utility but it is a right to attain ability to use water (Risse, 2013). Ideas under this belief have assured water as a fundamental right of commons (Bakker 2010). Like neoliberals, neo-Marxist discourse also refers to right to water as a subject of utility, however, for a different purpose. It has fundamentally argued for the transfer of right to use water with egalitarian values i.e. from water rich areas to water poor areas, from industry to agriculture and from agriculture to domestic purposes (Bakker 2003 and Shiva, 2001). It has argued that distribution of such nature will ultimately give water benefits to women and poor along with other vulnerable communities or groups (Cohon, 1975: Gleick, 2000: Krause, 2003: Lind, 1997: Robinson, 2002: Tol, 2002). Fundamentally, neo-Marxist scholars have raised their voice against the idea of mere utility and argued that water is a subject of morality and cannot be understood as a mere economic phenomenon (Shiva 2001). A group of neo- Marxist scholars including Bakker (2003), Kaika (2003), Swyngedouw (2004), Ganday (2008), Budds (2009), Loftus (2009), Linton (2010) and Roy (1999) have debated water as right and have insisted that globally it is a subject of human geography (biological need) and an element of social system (equal distribution of water).

\subsection{Observations:}

Certainly, in the theoretical discussions of right to water, neo Marxist perspectives have special value as it significantly insists upon water justice. However, the ideas are not defined well. It is quite unclear what actually they mean when they argue about establishing water as a right? Except justice i.e. equality, it is difficult to identify their principles and so it is not easy to defend or confront their argument. Neo Marxist perspective, with leftist approach in water management, arguing for water as a right of the poor, however it has ignored the fact that water is not a mere right to be given. The fact is that although nature has given water free, requirement of cost analysis is an unavoidable fact of water management. The limitation of this argument is that it is silent on the question as why a person will give water to someone through which s/he is not getting a desirable return. Another fact in this regard is that assuring rights are not always dependent on the will of the government. As in the case of right to water, the issue is dependent on the availability of water. Neo-Marxists have ignored this aspect of water. It is a fact that one can claim on water only if it is available. Since water is a natural resource the question arises is how the government can assure it for all, especially in a situation when it is not available. The fundamental question is how right to water can be claimed in a desert and what kind of political apparatus can assure its availability to people in general.

The limitations discussed above are not suspending the significance of neo Marxist interpretations. I observed that within the limits, it has a truth that water is life and valuing it as profit will devalue a life itself.

\section{ECO-FEMINIST PERCEPTION}

Feminism has discussed nature (water as part) as a feminist issue (Warren, 2000) ${ }^{17}$. It persistently argues (Charlotte Bunch, Shiva) that everything that happens in society, politics, economy and environment, affects women. Hence, every issue is a woman's issue and there is always a feminist perspective on every subject ${ }^{18}$. With this logic, arguments on water as a right are discussed with gender references (Gelles 2000; McCay and Jentoft 1998) which are studied and argued as eco-feminism (Griffin, 1978: Gaard, 1998: Plumood

${ }^{15}$ Here I have use the term New Discussions to indicate that in the academic world, water has not been explicitly discussed as a right. Water is studies as a forever subject of conflict within the state or between the states.

${ }^{16}$ For the detail study of global justice Movement and role of WB, WTO, and IMF, see: Bakker K (2004). An Uncooperative Commodity: Privatizing Water in England and Wales. Oxford: Oxford University Press Shiva Vandana (2002) Water Wars: Privatization, Pollution and Profit, India research press, New Delhi. D' Souza Radha. (2005). The Third World and Socio-Legal Studies: Neo-Liberalism and Lessons from India's Legal Innovations, Social and Legal Studies,14(4): 487-513.

${ }^{17}$ Here eco-feminism is not discussed as a form of feminism. However, it is discussed as a feminist argument found in Ecologism. Since idea of water as a right has argued to ascertain women as a preferential beneficiary, it is found important to discuss this under this particular heading.

${ }^{18}$ Cited in Bell Hooks, "Feminism: A Movement to End Oppressions", in Anna Coote and Ters Gill, ed., Women's Rights: A Practical Guide, 65-6, quoted in Abha Avasthi and A K Srivastava, eds., Modernity, Feminism and Women Empowerment (New Delhi: Rawat Publication, 2001)

DOI: 10.9790/0837-2203030108 $\quad$ www.iosrjournals.org $\quad 4 \mid$ Page


1999: Yamin 2005, 2012). Significantly, the argument of eco-feminists for water is not an argument in favor of all but it is insisting to make women the first beneficiary. As a thought it has argued that woman is the first possessor of right on water as Shiva's (1983) argues. For her, women are obvious and unnoticed preservers of water. She opines that use of drinking water and household water may affect men and women differently; especially in the situation of water scarcity women suffers more than men (Griffen, 1978: Gray, 1979: Spretnak. 1982: Shiva, 1983: Plumwood, 1993: Bleisch, 2006: Maria Mies (2009) as an eco feminist argues that a woman has a productive relationship with water because she not only collects and consumes what grows in nature but also makes things to grow ${ }^{19}$. Clearly, in the feminist approach the claim of a woman on water is not a claim for equality, but it is an argument beyond equality which advocates for special status of women in water rights, claimable in a cross cultural environment (Oakley, 1985) ${ }^{20}$. With this understanding, eco-feminism argues for new understanding on rights, evolved in between the idea of neoliberalism and Marxism. Noticeably, in compare to neoliberalism, values developed in eco feminism are nearer to neo-Marxist perceptions. Like neo Marxists, eco-feminists argue against the idea of privatization and emphasis depoliticisation of water through naturalization (Johnston 2003; Falkenmark 1997). They further persuade that private use of water is a threat to environmental integrity and the dominance of men over its use creates gender conflicts. To reconstruct the idea, it proclaims that the question of treating water as a right is not a mere right of infrastructure and technology but may refer to right to the water as a resource itself. While deciding on the question of right to water, it redefines who should be entitled the right to claim right and for what purpose (Boelens and Zwarteveen 2005).

\subsection{Observations:}

In the discourse of rights, perceptions, emerged with feminism have an important place because it has valued woman as a woman and in the social, political and economic structure has placed her as an individual. There is no denial on the idea of naturalization of right as it has respected nature with special regard. However my basic objection is in respect to gender perceptions, position of which is opposing the women centric tendencies, fundamentally developed in feminism. I believed that with this, eco feminism has fundamentally ignored human as a human. Argumentatively it appears that it has discarded man as a water user just because he is a man. I presume that instead of removing discriminations and privileges in water distribution, eco feminist perspective has created new space of differences as it demanded for the specific and separate water privileges for women. The perceptions of eco feminism are so generic that it has ignored the difference of class and caste. Since all women are not rich and all are not poor, it is wrong to say that all women should get equal preferential right on water that is over the right of a man. In the reference to eco- feminist perception, there are two fundamental questions. First is that how a rich woman can be a collector of water? And secondly, can a poor man cannot be a water collector and preserver? It is a surprise that while arguing against privatization, it has not discussed on the question of what if women is a single owner of water. I insist that since water is a biological need, originally it has nothing to do with gender. I argue that right to water is a matter of supply, for the domestic use it is supplied to a family, of which man and woman as an individual are members. This concludes that family lives and enjoys water as a collective unit. If a man or woman is denied to his/her right on water, it is not the violation of personal right but it is a violation of a right of a family. Eco feminism has unfortunately defined man and woman as an entirely different unit, and it is presumed that they are always living separately and always have a claim against each other. Herewith I want to clear that while discussing the problem of eco feminism, one cannot ignore a fact the argument of eco feminism i.e. right to nature itself is remarkable. It has created a sense of environment protection that is indeed in favor of entire humanity and indeed a serious requirement of our time.

\section{PERCEPTION OF HUMAN RIGHTS}

It is known that perspectives in human rights are fundamentally based on the egalitarian values. ${ }^{21}$ In the human right tradition, scholars (like Gleick1999: Angela Cassor Noemes 2004: Salman M. A. Salman, Siobhan

\footnotetext{
${ }^{19}$ Feminism, by principle, has placed women at the centre of power and studied issues in a political and power framework. Therefore, the value of right to water in feminism is studied, argued and confirmed with the principle of self-ownership of women over water resources. It opines that women have a natural relation with the environment and water. Women's independent ownership of resources has long been and continues to be an important item on agendas for gender equity; women's emancipation and liberation (see for elaborations of this plea Agarwal 1994; Deere and de Le, 2001).

${ }^{20}$ See Oakley, A. (1985). Sex, Gender and Society, 2nd Ed. London: Grower.

${ }^{21}$ Idea of human right is further developed with the international declaration on right to water. Chapter 4 will provide more details on this.
} 
Alice 2004: McLnerney Lankford 2004: Kunt Bourquaim 2008: E. Riedel 2008: Annanda Chahill Ripley: Risse 2013 and Inga T. Winker 2014) have discussed and upheld water as a basic right. It insists that water as a need has a common candidate and so it must be considered as a basic right, entitled to all. Significantly, in the content of human rights, virtue of universality is notably emphasized. It states that if people find themselves without water and their state cannot help, than the other agents existing in the global order must either make sure that they get water or else must facilitate them to move elsewhere (Martha, N. C. 2003). Such arguments have created cross border obligation that has extended the responsibility of states. Accordingly states are accountable to provide sufficient supplies of safe and drinkable water to all. It further advocates that globally, water management must be based on democratic principles like: non- discrimination and equality, access to information and transparency, participation, accountability and sustainability. It is found that in comparison to other understandings, arguments of human right on water is comprehensive (Roy 1999, Shah 2002, Shiva 1998), which significantly works universality (Baxi 2002, Abbas 1984, Gleick 1996).

\subsection{Observations:}

Indeed, the human right perspective has argued right to water as egalitarian value, which is a basic requirement of the idea. However, same is not free from limitation. The important argument is against the idea of universalism itself. For me the fundamental question is how water can be universally assured for all people, when it is rare and unevenly distributed by nature itself? It claims that it is the duty of the world community to provide and make water accessible and affordable to all humans as humans. However, the question is who will pay for the cost of arrangements for those who are living without water. Secondly from where water will come, why any state will give or supply a life giving resource for free? My argument is not against humanity but I want to point out that in the international regimes nothing is done for charity. At least the terms and conditions on which the World Bank is aiding the developing countries send out such a message. Thirdly, the nature and type of agricultural production are not same in all regions. Some land is more useful for grains which needs more water, if water will be given universally same, it will certainly effect the production of those grains which needs more water for cultivation.I observed that limitations of human rights have placed it in a unique position, where limitation can be claimed as strength as well. This is significant because it has given universal assurance to right to water, the responsibility to assure water as a right is not an obligation of one but it is an obligation of whoever is capable to do so which indeed includes private parties and NGOs. The only condition which is essentially required to be maintained is that the responsible parties must not cross their limits against humanity by interpreting right to water in favor of one individual, one group or one community.

\section{CONCLUSION}

The discussions presented in the paper revealed that there is absence of uniformity of ideas which has created noticeable paradoxes in key perspectives. My basic argument is that none of the perspectives are completely wrong or right. The notable absence of completeness is creating two problems. Firstly it makes water poor more vulnerable and secondly it creates confusion in policy making. For a just society both conditions are horrifying. I find that this is happening because the ideas are suffer from "isms" that has created one or other type of extremes. With inherent extremes, they are increasingly irrelevant as together they all have ignored some fundamental aspects of water, like availability of water in the specific region and the population of that area use water for domestic or other purposes. It is a fact that water can be made available as per its availability and as per the proportion of population. A state with less population can provide and assure more water accessibility than a populated state. In such a situation, limited water accessibility cannot be presumed as a failure of a state. Marxist arguments may work here, as it claims that every society has different needs. I agree that water is a trump right. However, it is a trump in a different sense as use of it depends on its availability, which is different in different societies. It is a bitter fact that water cannot be claimed as an all time right, the right automatically suspends at the time of natural calamity. The quality and quantity of water which is available today may not be available tomorrow. The question posed is that with known uncertainties, how water can be assured as right.

\section{BIBLIOGRAPHY}

[1] Adlersa, R., \& Zwarteveen, M. (2009). The water question in feminism: water control and gender inequities in a neo liberal era. Gender, Place and Culture , 409-426.

[2] Anand, P. B. (2007). Right to Water and access to water: An assessment. Journal of International Development, 511-526.

[3] Anderson, T. L. (1982). International Underpinings of the Water Crisis . Cato Journal, 759-792.

[4] Annabel, B. (1997). Liberty, Right and nature . Cambridge: Cambridge press.

[5] An-Na'im, A. (1992). Introduction. In A. An-Na'im, Human Rights in Cross-Culture Prespectives: A Quest for Consensus. philadelphia: University of Pennsylvania. 
[6] Antieau, J. C. (1960). Natural Rights and Founding Father- The Virginians. Washington and Lee Law Review , 43-79.

[7] Armstrong, A. (2006). Ethical issues in water use and sustainability . Area , 9-15.

[8] Ashford, E. (2009). In What Sense Is the Right to Subsistence a Basic Right . Journal of Social Philosophy, 488-503.

[9] Asthana,V. (2009). Water policy process in India: Discourse of Power and resistance . NewYork: Routledge

[10] Bakker K (2004). An Uncooperative Commodity: Privatizing Water in England and Wales. Oxford: Oxford University Press.

[11] Bakker, K. (2010). Privatizing Water: Governance Faliure and the World's Urban Water Crisis. Ithaca: Cornell Univeristy Press.

[12] Barlow, C. M. (2002). Blue Gold: The fight to stop the corporate theft of the World's water. New York: The New Press

[13] Branco, M. C., \& Damiao, P. H. (2012, Feb Thusay ). The Political Economy of The Human To Water (2008) Working paper. Varodara, Gujarat, India.

[14] Branco, M. C., \& Henriques, P. D. (2015, August 31). The Political Economy of the Human Right to Water. Retrieved from http://rrp.sagepub.com/subscriptions

[15] Barry, B. (2002). Culture and Equality. Cambridge : Harward.

[16] Bauer, J., \& Bell, D. A. (1999). The East Asian Challenge for Human Rights. Cambridge : Cambridge university press.

[17] Baxi, U. (2006). Future of Human Rights . Delhi: Sage.

[18] Cohen, G. A. (1978). Karl Marx's theroy of History . Oxford : Clarendan press.

[19] Chong, H., \& Sunding, D. (2006). Water markets and Trading . Annual Review of Environmental Resources, 239-264.

[20] D’Souza, R. (2014, October Wednesday 29). Liberal Theory, Human Rights and Water-Justice: Back to Square One? Varodara, Gujarat, India .

[21] Dworkin, R. (2000). Soveveign Virtue: The Theory and Practice of Equality . Cambridge: Harvard University

[22] Eisenstein, Z. (1981). The Radical Future of Liberalist feminism . London : Longman.

[23] Freeman, M. (2012). Human Rights: An interdiciplinary Approach . Cambridge : polity .

[24] Freeman, M. (1994). The Philosophical Foundations of Human Rights . Human Rights Quaterly, 491514.

[25] Finger, M., \& Allounche, J. (2002). Water privatization: Transnational corporations and the reregulation of water industry. London: Spon press.

[26] Frankena, W. K. (1955). Natural and Inalienable Rights. Philosophical Review , 212-232.

[27] Gewieth, A. (1981). Are There Any Absolute Rights. The Philosophical Quarterly, 1-16.

[28] Gewirth, A. (1992). Human Dignity as the Basis of Rights. In M. J. Meyer, \& W. A. Parent, The Constitution of Rights (pp. 10-28). Ithaca: Cornell University.

[29] Gewirth, A. (1982). Human Rights: Eassys on Justifications and Applications . Chicago: Chicago University Press.

[30] Gewirth, A. (1964). The Generalization Principles . The Philososphical Review , 229-242.

[31] Griffin, S. (1978). Women and Nature: The roaring inside her. New York: Haper And Raw.

[32] Harvey, D. (2007). A brief Hisory of Neoliberalism. Oxford : Oxford university press.

[33] Heller, A. (1976). The Theroy of Need in Marx . London: Allison and Busby.

[34] Hoffman, J. (2001). Gender and Sovereignty. Basingstoke: palgrave.

[35] Humm, M. (1992). Feminisms New York and London. Harvester: Wheatsheaf.

[36] Iyer, R. R. (2010). Water :Prespectives, Issues, Concerns. Delhi: Sage.

[37] Lee, M. (1985). North Korea \& the Western notion of Human Rights. In J. Hsiung, Human rights in an East Asian Prespective (pp. 129-140). New York : paragon.

[38] Lind, R. C. (1997). Intertemporal equity, discounting, and economic efficiency in water policy evaluation. Climatic Change, , 41-62.

[39] Lyons, D. (1969). Rights, Claimants and Beneficiaries . American Philososphical Quaterly, 173-185.

[40] MacKinnon, C. (1979). Toward a Feminist Theory of the state. Cambridge : Harvard University press.

[41] Mark, K., \& Engels, F. (1976). Manifesto of the Communit part. In Marx, \& Engels, Collected Works Vol 6 (p. 504). London.

[42] Marx, K. (1975). On the Jewish Quesion. In K. Marx, \& F. Engels, Collected Works Vol3 (pp. 146-174). Londaon .

[43] Martha, N. C. (2003). Capabilities as Fundamental Entitlements Sen and Social Critice . Feminsit Economics , 33-59. 
[44] Nordahl, R. (1991). A Marxisan Apprach to Human Rights. In A. A. Annaim, Human Rights in Cross Cutlure prespectives: A quest for consensus (pp. 160-175). Pennsylvania: universtiy of Pennsylvania press .

[45] Nozick Robert. (2013). Anarchy, State and Utopia, London: Basic Books.

[46] Nussbaum, M. (2000). Women and Human Develpoment: The Capabilities apprach . Cambridge : Cambridge university .

[47] Owen, D. (2001). Second Chance for private water? . Privaization Journal , 14.

[48] Plamentatz, M. E., \& Wokler, R. (1962). Man and Socity . London : Longman.

[49] Robinson, P. B. (2002). "All for some" water inequity in Zambia and Zimbabwe. Physics and Chemistry of the Earth, , 851-857.

[50] Ronald, D. (1984). Rights as Trumps. In J. Waldron, Theories of Right. Oxford: Oxford university.

[51] Rorty, R. (1989). Contingency, Irony and Solidarity . Cambidge : Cambridge.

[52] Sacks, K. (1974). Engels Revisited: Women, the organization of production and private property. In M. Rosaldo, \& L. Lamphere, Women, Culture and Society Stanford (pp. 207-22). Calif: Standford University Press.

[53] Hare, R. M. (1982). Utility and Rights: Comment on David Lyons' s essay. In J. R. Pennock, \& J. W. Chapman, Ethic Economics and the Law (p. 153). New York: New York University press.

[54] Harel, A. (2015, 07 28). Theories of Rights. Varodara, Gujarat, India.

[55] Hart. (1979). Between utility and Rights. In Ryan, The idea of Freedom. oxford : Oxford university .

[56] Hart, H. A. (1955). Are there any Natural Rights. The Philosophical Review , 175-191.

[57] Harvey, D. (2007). A brief Hisory of Neoliberalism . Oxford : Oxford university press.

[58] Harvey, D. (2003). The New Imperialism . Oxford : oxford university press.

[59] Hasnas, J. (2005). Towards a theory of empirical nature. USA: Social philosophy and policy foundation.

[60] Marston, A. (2013). Autonomy in a Post-neolberal era: Community water Governance in Cochabamba, Bolivia. Geoforum , 1-11.

[61] Petrella Ricardo. (2001). The Water manifesto: Arguments for a World Water contract, Bangalore: Books for Change.

[62] Petto, P. (2015, Auguest 31). Rights, Constrains And Trumps. Retrieved from http/:analysisoxfordjournals.org.

[63] Shiva, V. (2001). Water Wars: Privatization, pollution and profit. London: Pluto Press.

[64] Smith, J. (2008). Social Movements for global democracy. Baltimore: The Johns Hopkins University press.

[65] Sunding, D. (2000). The price of Water: Market Based Stratergies are needed to Copr with Scarcity . California Agricutlure , 56-63.

[66] Yang, H. Z. (2003). Water scarcity, pricing mechanism and institutional reform in northern. Agricultural Water Management, 143-161.

[67] Yang, W. H., \& Weersink, A. (2004). Cost effective targeting of riparian buffers . Journal of Agriculture and Economices , 17-34 